\title{
Attrition from Health Professional Schools in a Canadian University
}

\author{
MIRIAM J. STEWART*
}

\begin{abstract}
A descriptive study was conducted in order to identify the incidence of student voluntary withdrawal from undergraduate programs of the schools of the Faculty of Health Professions, in a Canadian university, over a two-year period; to identify students' expressed reasons for voluntary withdrawal; and, to develop a profile of characteristics of students who withdraw voluntarily and those who are successful academically and continue/persist through to graduation. There were 30 respondents from among the 42 withdrawing students (73.2\% response rate) and 85 respondents from among 120 eligible graduates sampled $(70.8 \%$ response rate). Dropouts from the health professional schools in this Canadian university were typically older, married, and employed; considered their program less difficult; had not participated in orientation or contacted writers' workshop, clubs, sports teams, student health, faculty advisors, or their profession's clientele. These characteristics appear to reflect facets of academic integration more than social integration. Former students cited dissatisfaction with the program/curriculum content, uncertainty about educational/occupational goals, and stress associated with the profession as the three most important reasons for voluntary withdrawal.
\end{abstract}

\section{RÉSUMÉ}

Une étude descriptive a été menée dans le but premièrement de déterminer quel était le nombre moyen d'étudiants qui, sur une période de deux ans, se retiraient des cours de la Faculté des sciences de la santé d'une université canadienne auxquels ils s'étaient inscrits; deuxièmement d'inventorier les raisons pour lesquelles ces étudiants avaient quitté leurs cours; et troisièmement de dégager le profil des étudiants susceptibles d'abandonner leurs cours et celui de ceux qui ont des chances de réussir et de persévérer jusqu'à l'obtention de leur diplôme. Trente des 42 étudiants ou étudiantes ayant quitté leurs cours (soit 73,2\%) et 85 des

*School of Nursing, Dalhousie University

The author gratefully acknowledges the assistance of Kevin Canavan, data analyst, Grace Maternity Hospital, Halifax, Nova Scotia 
120 futur(e)s diplômé(e)s (70,8\%) ont répondu au sondage. Les étudiants qui avaient abandonné leurs cours à la Faculté des sciences de la santé de cette université canadienne étaient d'une façon générale plus âgés que les autres, ils étaient mariés, travaillaient, trouvaient leurs cours moins difficiles que les autres étudiants, n'avaient jamais suivi de sessions d'orientation, ne faisaient partie ni d'ateliers d'écriture ni de clubs ni d'équipes sportives, n'avaient jamais eu affaire aux organismes étudiants de santé, aux conseillers pédagogiques ni à la clientèle visée par leur profession. Ces étudiants se disaient mécontents du contenu des programmes, incertains de leurs objectifs professionnels ou académiques, et inquiets relativement aux exigences de la profession. Ces trois points figuraient parmi les raisons les plus importantes qui les avaient conduits à abandonner leurs cours.

The escalating costs of tuition, the present state of financial stringency in universities and health care systems, and shortages of some health care professionals all point to the need to consider the costs of health professional student attrition. Most research efforts cited in the relevant literature seem to focus on students withdrawing from medicine (e.g., Alexander \& Haldane, 1980; Aldrich, 1987) or nursing (e.g., Munro, 1980; Rosenfield, 1988), not other health-related disciplines. Furthermore, Canadian health professional students, who will work in a unique health care delivery system, appear to have been overlooked.

Accordingly, a descriptive study was conducted in order to

1. identify the incidence of student voluntary withdrawal from undergraduate programs of the schools of the Faculty of Health Professions, in a Canadian university, over a two-year period,

2. identify students' expressed reasons for voluntary withdrawal, and

3. develop a profile of characteristics of students who withdraw voluntarily and those who are successful academically and continue/persist through to graduation.

\section{THEORETICAL FRAMEWORK}

The most comprehensive and defined theory of attrition was initially advanced by Spady (1971) and extended by Tinto $(1975,1982)$. Tinto $(1975,1986)$ views an individual's academic and social integration into an institution of higher learning as the primary determinant of "persistence". He postulates that integration into and commitment to the academic system of the university most directly affect commitment to and integration of educational goals. Attrition is seen as a multidimensional process. Thus, this predictive theory specifies a role for antecedent variables such as pre-college schooling, personal attributes, and social background. 
Tinto differentiates between temporary (transfer) and permanent withdrawal and between voluntary withdrawal and academic failure and dismissal. Variations in forms of dropout behaviour and interaction processes between individuals and institutions were to be explained by his "institutional model". Lack of congruency between the individual and the intellectual climate of the institution and the social system of peers was said to contribute to attrition. Tinto (1986) noted, however, that his model does not give sufficient emphasis to the role of finances, social status and race background in the matter of higher-education persistence.

Munro (1980), who adapted Tinto's conceptual schema for "dropout" or withdrawal from an institution of higher learning, found that parental and student educational aspirations affect goal commitment more than does social integration. Pascarella (1986) employed a causal model based on Tinto's work to explain long-term persistence/withdrawal in two-year post-secondary institutions and confirmed both measures of integration. Stoecker, Pascarella and Wolfe's (1988) study supports Tinto's theoretical model of persistence/withdrawal, using a national, multi-institutional sample followed for 9 years. Beltzer's (1985) study supported the predictive validity of the Tinto model in identifying potential dropouts. Hence, the theoretical perspective used in this study was guided by components of Tinto's conceptual scheme on dropout from higher education, specifically, personal and family attributes, commitments (goal, institutional), academic system (intellectual development) and social system (peer-group interactions, faculty interactions), which in turn influence academic and social integration and thereafter dropout decisions. This schema guided the development of the data-gathering tool and the data analysis.

\section{LITERATURE REVIEW}

The general attrition literature in higher education offers some interesting insights regarding factors influencing attrition. Pantages and Creedon (1978) summarize the literature on withdrawal from institutions of higher learning and cite the reasons students give in the following order: 1) academic (poor grades and dissatisfaction with curriculum), 2) financial, 3) motivational (uncertainty about educational and occupational goals, lack of interest in studies, unwillingness or inability to study), 4) personal (emotional problems, problems of adjustment to college life, marriage, student or family illness), 5) dissatisfaction (with college life, social and academic environment) and 6) full-time employment.

The degree to which student values and attitudes correspond with the institution is the degree to which they are likely to persist when grades are good. Tinto (1975) found that students withdrawing voluntarily from large institutions have higher grade performance, levels of intellectual development and social status than the average "persisters" (grade performance being the single strongest predictor of academic dismissal). Low commitment to goals leads to permanent withdrawal, whereas voluntary withdrawal with a high commitment to goals is a prelude to upward or horizontal transfer. 
The literature review focused primarily on undergraduate allied health professional students. This was based on two assumptions: 1) students who select professional schools may be more career-oriented than students in general B.A. and B.Sc. programs; and 2) students in undergraduate health professional programs may differ from those in medicine and dentistry graduate programs in that they have not yet demonstrated academic success in university programs.

Nursing studies yield some significant associations. The major reasons given for withdrawal included changes in career, difficulties with the basic-science component, perceived inability to work with the ill, difficulties experienced in adjusting to the campus/school/institution, failure to maintain a satisfactory grade point average (GPA) (Knopke, 1979); family responsibilities, conflicting lifestyle choices, disinterest in career, an unrealistic appraisal of the profession; poor self-esteem, loss of interest in the profession chosen due to a basic lack of clear understanding of one's role in the profession and of the associated career opportunities (McGuire, Foley, Gorr, \& Richards, 1983; Munro, 1980), stress, and unsuitability for the profession (Lindop, 1987). Valid predictors of academic success in nursing education include intention to complete the course, motivation, family support, not working, nursing GPA, prenursing GPA, previous educational attainment, personality characteristics, socioeconomic status, perceived parental aspirations, goal commitment and ethnicity (Alichnie \& Bellucci, 1981; Billings, 1987; Munro, 1980; Oliver, 1985; Seither, 1980).

Withdrawal of minority students in nursing has been attributed to previous educational handicaps, ongoing cultural experience, inadequate financial aid, feelings of alienation and loneliness, inadequate secondary-school preparation and cultural/racial identity adjustments, (Allen, Nunley \& Scott-Warner, 1988; Oliver, 1985). The few studies of health professional schools outside of medicine and nursing reveal that attrition was higher for minority students, varying with prior level of clinical responsibility in a physician-assistant program (Garcia \& Fowkes, 1987), lower preentry grades and lower entrance-examination grades, ratio of "advantage factors" (academic and psychological) to "risk factors" in optometry school; difficulty taking tests, problems in relationships and, employment (Kegel-Flom, 1986). Motivation and commitment variables appeared more important than academic ability or social/academic integration factors in dropouts from an allied health education program (dental auxiliaries, technicians, nursing).

In sum, there can be no doubt about the multivariate nature of attrition: a complex interaction of diverse personal, academic and organizational factors is involved. To overcome deficiencies in some attrition research, Tinto (1986) and Pantages and Creedon (1978) recommended longitudinal analyses for long-term study of attrition from a particular institution. They advise that for those students who withdraw from a college, an exit interview and follow-up questionnaire be mandatory; that the differences between student-recorded reasons and counsellorperceived reasons be obtained, as student attitudes are ambivalent and should be supplemented by other data sources; and that continuing and "drop out" students be compared. Furthermore, no studies have focused on withdrawal from schools 
of occupational therapy, pharmacy, physiotherapy, health education and physical education (i.e., schools outside of medicine), although nursing has received some attention. Finally, although the Canadian literature (e.g. Dennison, Forrester \& Jones, 1982; Gilbert \& Auger, 1987; Pascal \& Kanowitch, 1979; Stuhr, 1987; Ungar, 1980) is generally instructive, attrition specifically from health professional schools in Canada requires investigation.

Thus the research questions posed for this study were:

1. What are the characteristics of students who withdraw voluntarily from health professional schools?

2. What are the characteristics of health professional students who persist through to graduation?

3. What are the perceived reasons for voluntary withdrawal of health professional students?

\section{METHODOLOGY}

\section{Sample Population}

A "convenience" sample consisting of all students who withdrew from the undergraduate programs in the health professions schools of physiotherapy, occupational therapy, health education, pharmacy, physical education, and nursing from September 1, 1983, through September 1, 1985, was selected. One-third of graduating students from each health professional school was randomly sampled by April 1, 1984 and 1985 .

\section{Survey}

A questionnaire entitled "Faculty of Health Professions Student Withdrawal Questionnaire" (Appendix I) was administered by the adviser/director/program coordinator to each student withdrawing from the school/college when this final decision was made known to the school. The questionnaire solicited information about knowledge and perceptions. Students were asked to comment on university services known to and contacted by them, methods of instruction which helped them learn, contact with clients, goal commitments, views of the profession, friendships, three most important reasons for withdrawal, and perceptions of their withdrawal and of their experience in that school. The questions were based on the literature review and the theoretical framework but were developed uniquely for this study. Thus items focused on facets of academic and social integration, identified earlier, including intellectual development and interactions with faculty and peers. Most were closed-ended to facilitate computer coding; a few open-ended queries and "other" categories facilitated freedom of responses. The student was asked to return the completed questionnaire when he/she handed in his/her student card. The adviser/director then recorded the first semester GPA (if available), subsequent GPA for each year at the university, and his/her perceptions of the type of withdrawal and reasons for the student's withdrawal. The form to be 
completed by the adviser/director had the same subject number as the student questionnaire.

The students graduating from the schools/college were asked to complete a questionnaire, entitled "Faculty of Health Professions Graduating Student Questionnaire", that was identical to that given to withdrawing students except that it did not have sections IX and X (a) and (b).

\section{Ethical Considerations}

Students were told that they had the right to refuse to participate, that numbers (not names) would be used on the questionnaires (ensuring anonymity), and that all results would be coded. The purpose, risks, and benefits of the study was explained in a covering letter. It was acknowledged that the student was leaving presumably under some form of duress, internally or externally imposed, and hence might feel obligated to comply. However, future students might benefit through the development of comprehensive preventive services, criteria for high-risk target groups and altered educational environs.

\section{Data Analysis}

Responses were coded and computer-analyzed. Frequencies of characteristics of voluntary withdrawals and continuing/persisting students were identified and categorized according to the theoretical perspective of academic or social integration. When the responses to the questionnaire were dichotomous, (e.g., sex, part-time/full-time), two-way contingency tables of the response by group ("Study" group = withdrawn students vs "control" group = graduating students) were created and analyzed by means of traditional chi-square techniques. When the responses were not dichotomous but represented orderings, the Mann-Whitney ranks test was used (Id, V, VIIIe). For questions with non-dichotomous responses without ordering (e.g., questions I (b), (f), country of origin; IId type of employment), tables of each response against all other responses by group were set up and analyzed by means of chi-square techniques. Table 1 shows the significant results of the three methods of analysis described above. The Statistical Package for the Social Sciences (SPSS) was used to perform the analyses.

\section{Sample}

\section{RESULTS}

There were 30 respondents from among the 42 withdrawing students $(73.2 \%$ response rate) and 85 respondents from among 120 graduates sampled (i.e., $70.8 \%$ response rate). There was a $2.5 \%$ attrition rate. Of the 24 dropouts who gave the year of the program in which they withdrew, 10 were in Year 1, 5 in Year 2, 8 in Year 3 and 1 in Year 4. The distribution according to program was as follows: Recreation (3), Pharmacy (7), Occupational Therapy (2), Health Education (2), Physical Education (1), Nursing (12), Physiotherapy (1), unspecified (2). 
TABLE 1

PROFILE OF CHARACTERISTICS OF HEALTH PROFESSIONAL. DROPOUTS AND PERSISTERS

$\begin{array}{ccc}\text { DROPOUTS } & \begin{array}{c}\text { PERSISTERS } \\ (n=30)\end{array} & (n=120) \\ x & \% & P\end{array}$

\section{Personal/Family Attributes}

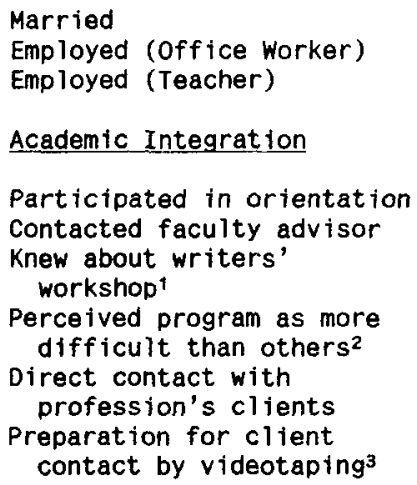

Social Integration

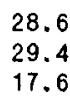

8.5

.0189

5.9

.0298

17.6

2.0

.0455

$\begin{array}{lll}29.2 & 59.4 & .0205 \\ 53.3 & 83.5 & .0022 \\ 43.3 & 68.2 & .0282 \\ 56.3 & 97.6 & .0003 \\ 73.1 & 97.6 & .0003 \\ 72.7 & 95.2 & .0390\end{array}$

Contacted clubs ${ }^{1}$

Contacted sports teams'

Contacted student hea 1 th $^{1}$

\section{7 \\ 13.3 \\ 43.3}

40.0

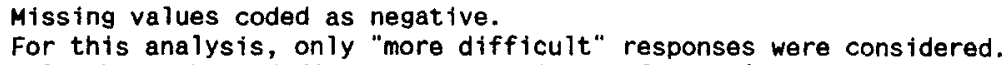

\section{Demographic Variables}

There is a significant difference in the ages of the two groups, with the graduating students being, on average, older by approximately one year. A larger percentage of graduates $[\mathrm{N}=72(87.8 \%)]$ than dropouts $[\mathrm{N}=19(67.9 \%)]$ are single and, not surprisingly, a smaller percentage of graduates $[\mathrm{N}=7(8.5 \%)]$ than dropouts $[\mathrm{N}=$ $8(28.6 \%)]$ are married. A larger percentage of withdrawing students were employed in such occupations as office workers and teachers while at university. There was no significant difference between groups in country of origin and language used at home. Furthermore, there was no significant difference in gender between dropouts [males $\mathrm{N}=5(16.7 \%)$; females $\mathrm{N}=25(83.3 \%)$ ]; and graduates [males $\mathrm{N}=15(17.6 \%)$; females $\mathrm{N}=70(82.4 \%)$ ]. 


\section{College Entrance Procedures}

The only significant result in this category is that a higher percentage of graduates participated in orientation.

\section{University Services}

The design of the questionnaire makes it likely that many participants in the study would only respond in the affirmative to this group of questions. It is therefore likely that non-responses should be treated as negative responses rather than as missing responses. When non-responses are treated as negative responses there are several significant differences:

1. A larger proportion of graduates knew about the writers' workshop.

2. A larger proportion of graduates contacted clubs.

3. A larger proportion of graduates contacted sports teams.

4. A larger proportion of graduates contacted student health.

5. A larger proportion of graduates contacted the faculty advisor.

\section{Methods of Instruction}

In this case, Mann-Whitney ranks tests were performed with no significant results.

\section{Contact with Clientele of their Profession}

A larger proportion of graduating students experienced direct contact with (gave care to/coached/taught) the clients of their profession. The rest of the categories were examined only for cases where the student experienced direct contact. A larger proportion of graduating students prepared for this contact by videotaping.

\section{Difficulty of Program}

A $2 \times 2$ contingency table containing only the "more difficult" and "less difficult" responses reveals that a significantly larger proportion of graduating students believe that their program is more difficult than other programs. Content analysis revealed that graduates refer to their programs as having higher expectations, requirements, or criteria than other non-professional programs, while those dropouts who believed their program was more difficult cited heavier workloads than their peers. For example, some leavers commented that "I put in many more hours of study daily", that there was a "large volume of material to cover", or that "the work is time consuming but not brain straining". It was interesting that one dropout observed that the "program workload is geared to the young single person". 
TABLE 2

RANKED REASONS FOR WITHDRAWAL

\begin{tabular}{|c|c|c|c|c|c|c|c|c|}
\hline \multirow[b]{2}{*}{ REASON FOR WITHDRAWAL } & \multicolumn{2}{|c|}{$\begin{array}{l}\text { RANKED } \\
\text { FIRST }\end{array}$} & \multicolumn{2}{|c|}{$\begin{array}{l}\text { RANKED } \\
\text { SECOND }\end{array}$} & \multicolumn{2}{|c|}{$\begin{array}{r}\text { RANKED } \\
\text { THIRD }\end{array}$} & \multicolumn{2}{|c|}{$\begin{array}{l}\text { TOTAL TIMES } \\
\text { CITED \& } \\
\text { OVERALL } \\
\text { RANK }\end{array}$} \\
\hline & $N$ & $\mathbf{x}$ & $\mathbf{N}$ & $\approx$ & $N$ & x & $N$ & $\begin{array}{l}\text { RANKED } \\
\text { ORDER }\end{array}$ \\
\hline \multicolumn{9}{|l|}{ Academic Integration } \\
\hline $\begin{array}{l}\text { Poor grades } \\
\text { Dissatisfaction with the }\end{array}$ & 1 & 3.4 & 1 & 4.0 & 1 & 4.5 & 3 & 7 \\
\hline $\begin{array}{l}\text { program/curriculum content } \\
\text { Inadequate study habits/work }\end{array}$ & 8 & 27.6 & 6 & 24.0 & 2 & 9.1 & 16 & 1 \\
\hline $\begin{array}{l}\text { habits } \\
\text { Uncertainty about educational/ }\end{array}$ & 1 & 3.4 & - & - & 4 & 18.2 & 5 & 5 \\
\hline $\begin{array}{l}\text { occupational goals } \\
\text { stress associated with university }\end{array}$ & 3 & 10.3 & 8 & 7.0 & 2 & 9.1 & 13 & 2 \\
\hline $\begin{array}{l}\text { education } \\
\text { Stress associated with profession } \\
\text { Dissatisfaction with ability/ }\end{array}$ & $\begin{array}{l}3 \\
2\end{array}$ & $\begin{array}{r}10.3 \\
6.9\end{array}$ & $\begin{array}{l}2 \\
2\end{array}$ & $\begin{array}{l}1.7 \\
1.7\end{array}$ & $\begin{array}{l}1 \\
3\end{array}$ & $\begin{array}{r}4.5 \\
13.6\end{array}$ & $\begin{array}{l}6 \\
7\end{array}$ & $\begin{array}{l}4 \\
3\end{array}$ \\
\hline know ledge of professors & - & - & 1 & 4.0 & - & - & 1 & 9 \\
\hline \multicolumn{9}{|l|}{ Social Integration } \\
\hline $\begin{array}{l}\text { Difficulty adjusting to this } \\
\text { university } \\
\text { Lack of support/assistance at }\end{array}$ & - & - & - & - & - & - & 0 & 10 \\
\hline $\begin{array}{l}\text { university } \\
\text { Dissatisfaction with campus }\end{array}$ & - & - & 1 & 4.0 & 2 & 9.1 & 3 & 7 \\
\hline soctal life & - & - & - & - & 1 & 4.5 & 1 & 9 \\
\hline $\begin{array}{l}\text { Personal and Family Attributes } \\
\text { Influencing Both Types of } \\
\text { Integration Via Commitments }\end{array}$ & & & & & & & & \\
\hline $\begin{array}{l}\text { Financial difficulty } \\
\text { Moving to another province/ }\end{array}$ & 3 & 10.3 & - & - & 1 & 4.5 & 4 & 6 \\
\hline country & - & - & 1 & 4.0 & - & - & 1 & 9 \\
\hline Persona? 111ness or injury & - & - & - & - & - & - & 0 & 10 \\
\hline Family illness or injury & - & - & 1 & 4.0 & 1 & 4.5 & 2 & 8 \\
\hline Marrlage & 2 & 6.9 & 1 & 4.0 & 1 & 4.5 & 4 & 6 \\
\hline
\end{tabular}

\section{Rank Order of Three Most Important Reasons for Withdrawal}

The most prevalent reason for withdrawal (Table 2) is "dissatisfaction with the program/curriculum content", which was cited 16 times. The second most prevalent reason, "uncertainty about educational/occupational goals", was cited 13 times. "Stress associated with the profession" was ranked by seven as the third most prevalent reason of 16 possible reasons; "other" reasons cited for withdrawal included (in order) lack of motivation, inconvenient location, changing to a non-health-professional faculty, lack of interest in the profession, loss of faith in the profession, and boyfriend at home. These open-ended responses would be 
classified as academic integration and personal. There was no significant difference in reasons cited for withdrawal from different years of the programs.

\section{Future Plans}

The two most common plans for the future for dropouts are to "transfer to another university" and "seek employment". A few thought they might return later.

\section{DISCUSSION OF FINDINGS}

There are several interpretations of these findings (see italics) when contrasted to pertinent findings in the literature. These can be discussed in terms of the elements of the theoretical framework. The $2.5 \%$ attrition rate was much lower than rates generally identified for other Canadian undergraduate programs (e.g., Pascal \& Kanowitch, 1979; Dennison et al., 1982), perhaps because professional students are more career oriented and/or, as Dennison et al. (1982) note, because professional programs' small size, cohesive units, and compact curricula may support their students.

\section{Personal and Family Attributes:}

The findings that graduating students are, on average, the older student might be explained by the extra years required to complete the program. (Oliver (1985) found successful students characteristically older and having previously attended college). The difference, although significant in this study, was less than one year. The fact that one-third of dropouts left in the freshman year is consistent with the literature on student attrition, as there is increasing recognition that the problem of student attrition is most serious and prevalent among first-year students (e.g., Bee \& Beronja, 1984; Nelson, Scott \& Bryan, 1984; Tinto, 1982). Tinto (1982) suggests that the forces that lead to early withdrawal may differ from forces leading to later withdrawal. Finally, it is conceivable that dropouts might be less academically and socially integrated than persisters, simply because of their shorter duration on campus.

A smaller proportion of persisting students (8.5\%) than dropouts $(28.6 \%)$ were married, which may indicate that familial and financial responsibilities for dependents, for example, undermine persistence. However, there was no significant difference between groups in numbers of dependents. This may also create stress, which was found by Lindop (1987) to lead to attrition. Marriage was cited in Oliver's (1985) study as a reason for dropping out. Parkinson (1987) found that inability to resolve pressures from home, work and study resulted in decisions to drop out.

There were more females who withdrew $(83.3 \%)$ and who graduated $(82.4 \%)$ than males, yielding no significant difference between the two groups - perhaps in part because some professions are female-dominated. There were no significant 
differences $(p=1.0)$ between males and females who withdrew or persisted in this study. This is surprising in that prior research indicates that gender has a strong bearing on field of study within higher education. Dennison et al. (1982) confirmed that females have better academic performance. Typically there are fundamental gender differences in transition to university because of juggling personal, work, financial, educational and family/child care responsibilities (Guppy \& Pendakur, 1989; Smallwood, 1980). This can create problems of role incompatibility. Hence, there has been an associated dramatic increase over time of women in part-time enrolment (Anisef, 1989; Report, 1985).

Part-time study has acted as an entry point to higher education for married and older women (Guppy \& Pendakur, 1989). This study regrettably did not explicitly examine full-time/part-time status, except to indicate that some withdrawing students had a job. (Part-time students in Canada have less advantaged family backgrounds than full-time students (Report, 1985)). However, computerized information on attrition from the study university indicates that over the past five years $54.5 \%(\mathrm{~N}=128$ of 235$)$ of university dropouts from health professional schools were part-time and $45.5 \%(\mathrm{~N}=107$ of 235$)$ were full-time status at the time of withdrawal. (Chi Square analysis revealed that this was not a statistically significant difference). In most of the health professional schools, the large majority of students are full-time; indeed, a few schools used to preclude part-time study although this is changing. Nursing and social work schools are exceptional in this health professional faculty in permitting greater access to part-time study, which seems to account for most of the differences observed. Nursing and social work dropouts, in contrast to those from other health professional schools, more frequently had part-time than full-time status. Finally, there is a definitional problem at this institution and others in identifying "true" part-time study because of the shifting back and forth between full-time and part-time status before graduation. The registrar's office does not keep information on the attendance status of its graduates for this reason. This difficulty in tracing the university careers of persisting part-time students is reinforced by Anisef (1989), Devlin (1989) and Morris (1987) among others.

More students who were employed in specific occupations on a part-time basis (e.g., teaching, office work) withdrew. Ungar (1980) observed that enrolment attrition occurred in part as a result of students' awareness of viable alternatives, such as the availability of a job. Billings (1987) found that students who were not working were more likely to complete courses. Gilbert and Auger (1987) suggest that financial hardship and availability of attractive employment alternatives may be necessitating forces in withdrawal.

\section{Academic System and Institutional Commitment}

Results seem to indicate that those who have used student services, both formal and informal, tend to persist, although graduating students may simply have had more time than withdrawing students to use such services. Clearly both social 
integration and academic integration are important here. More graduates contacted health services, which seems interesting in light of their chosen profession and the fact that they acknowledged and sought assistance with health-related concerns. Ill health was one reason cited for dropping out in Oliver's (1985) study, although no dropouts in the present study identified this as a cause.

A significantly larger proportion of the students who participated in orientation persisted. This may be due to an especially intense orientation in the year that most of the graduates would have started. Pantages and Creedon (1978), Blanc, de Buhr and Martin (1984), Prola and Stern (1984) and others contend that orientation programs minimize potential for withdrawals. More graduating students knew about the writers' workshop, which assisted students to develop and refine skills associated with written assignments. This could influence academic integration through long-term impact on grades, and short-term impact on perception of personal intellectual development. Munro (1985) indicated that the essay had the highest correlation with successful completion of graduate level work.

\section{Faculty Interactions}

Furthermore, a larger proportion of graduates had contact with their faculty advisor, which could facilitate academic integration. However, Gomme and Gilbert (1984) note that social integration is viewed as a function of both formal and informal interaction with peers and "more importantly with faculty". The impact of faculty in teaching and non-teaching roles influences decisions to dropout or persist (Pascarella \& Terenzini, 1977). Tinto (1982) claims that informal interaction with faculty outside the classroom is especially significant for integration and there is a need for frequent formal contact for student advisement. High achievement of adult health professional students was linked to collaborative relationships with teachers (Welborn, 1986). Clearly the faculty-student relationship and personal contact with faculty are related to retention (Allen et al., 1988; Gilbert \& Auger, 1987; Gilbert \& Gomme, 1986; Gomme \& Gilbert, 1984).

\section{Peer-Group Interactions}

In the context of social integration, more graduates contacted sports teams and clubs on campus. However, as in Bee and Beronja's (1984) findings, social life was not cited as a major reason for withdrawal. Furthermore, there was no difference in close friendships in the school, university, and city. Leavers were less positive than persisters about ease in making friends and expectations regarding social life in Gilbert and Auger's (1987) research. 
TABLE 3

GOALS, MOTIVATIONS AND GAINS

\begin{tabular}{|c|c|c|c|c|c|}
\hline \multirow[t]{2}{*}{$\begin{array}{l}\text { GOALS/ } \\
\text { GAINS }\end{array}$} & \multirow[t]{2}{*}{ TYPICAL RESPONSES } & \multicolumn{2}{|c|}{ GRADUATES } & \multicolumn{2}{|c|}{ DROPOUTS } \\
\hline & & $\mathbf{N}$ & 2* & $N$ & \%* \\
\hline $\begin{array}{l}\text { Entering } \\
\text { Goals }\end{array}$ & $\begin{array}{l}\text { Enter profession/field } \\
\text { Obtain a degree } \\
\text { Get into graduate school } \\
\text { Make parents happy } \\
\text { Help people/clients }\end{array}$ & $\begin{array}{r}25 \\
15 \\
1 \\
1 \\
-\end{array}$ & $\begin{array}{r}59.5 \\
35.7 \\
2.4 \\
2.4 \\
-\end{array}$ & $\begin{array}{l}7 \\
6 \\
- \\
- \\
3\end{array}$ & $\begin{array}{c}43.8 \\
37.5 \\
- \\
- \\
18.7\end{array}$ \\
\hline $\begin{array}{l}\text { Present } \\
\text { Goals }\end{array}$ & $\begin{array}{l}\text { To be a health professional } \\
\text { To help public/people } \\
\text { Enter graduate school } \\
\text { Spectalize/keep on learning } \\
\text { Enter different health profession } \\
\text { school } \\
\text { Return to this university } \\
\text { Enter field suited to me } \\
\text { Enter new field outside of health }\end{array}$ & $\begin{array}{r}27 \\
7 \\
5 \\
2 \\
- \\
- \\
- \\
-\end{array}$ & $\begin{array}{r}65.9 \\
17.0 \\
12.2 \\
4.9 \\
- \\
- \\
- \\
-\end{array}$ & $\begin{array}{l}1 \\
1 \\
6 \\
2\end{array}$ & $\begin{array}{r}23.1 \\
- \\
- \\
- \\
7.7 \\
7.7 \\
46.7 \\
15.4\end{array}$ \\
\hline $\begin{array}{l}\text { Initial View } \\
\text { of Profession }\end{array}$ & $\begin{array}{l}\text { Positive/interesting, rewarding } \\
\text { Negative/difficult } \\
\text { Uncertain, inaccurate/incomplete } \\
\text { reality }\end{array}$ & $\begin{array}{r}21 \\
9 \\
8\end{array}$ & $\begin{array}{l}55.3 \\
23.7 \\
21.0\end{array}$ & $\begin{array}{l}7 \\
4\end{array}$ & $\begin{array}{l}53.8 \\
30.8 \\
15.4\end{array}$ \\
\hline $\begin{array}{l}\text { View } \\
\text { Changed }\end{array}$ & $\begin{array}{l}\text { More positive re: profession } \\
\text { More negative re: profession } \\
\text { Unchanged } \\
\text { More negative re professional } \\
\text { school/curriculum } \\
\text { know profession not for them } \\
\text { personally }\end{array}$ & $\begin{array}{r}21 \\
8 \\
6 \\
- \\
-\end{array}$ & $\begin{array}{r}60.0 \\
22.9 \\
17.1 \\
- \\
-\end{array}$ & $\begin{array}{l}- \\
3 \\
-\end{array}$ & $\begin{array}{c}- \\
27.3 \\
- \\
45.4 \\
27.3\end{array}$ \\
\hline $\begin{array}{l}\text { Motivation } \\
\text { to Enter } \\
\text { School }\end{array}$ & $\begin{array}{l}\text { Desire to obtain a health } \\
\text { professional university education } \\
\text { Convenience factors (e.g. location) } \\
\text { Reputation } \\
\text { Encouragement of others } \\
\text { Job dissatisfaction }\end{array}$ & $\begin{array}{r}21 \\
8 \\
4 \\
2 \\
2\end{array}$ & $\begin{array}{r}56.8 \\
21.6 \\
10.8 \\
5.4 \\
5.4\end{array}$ & $\begin{array}{l}6 \\
- \\
3 \\
5 \\
2\end{array}$ & $\begin{array}{c}37.5 \\
- \\
18.8 \\
31.3 \\
12.4\end{array}$ \\
\hline $\begin{array}{l}\text { Gains } \\
\text { from } \\
\text { Experience }\end{array}$ & $\begin{array}{l}\text { Enhanced personal skills, } \\
\text { (communication, interpersonal, } \\
\text { decision making, analysis) } \\
\text { curricular changes required } \\
\text { Enhanced knowledge of that } \\
\text { profession } \\
\text { Learned about self values, } \\
\text { abilities }\end{array}$ & $\begin{array}{r}25 \\
- \\
13\end{array}$ & $\begin{array}{c}65.8 \\
- \\
34.2\end{array}$ & $\begin{array}{l}6 \\
4\end{array}$ & $\begin{array}{r}37.5 \\
25.0 \\
- \\
37.5\end{array}$ \\
\hline
\end{tabular}

* * of total respondents to each question, as $\mathrm{N}$ differs in these open-ended questions. 


\section{Intellectual Development}

Dissatisfaction with the program/curriculum content was the most prevalent perceived reason for withdrawal. This was supported in responses to open-ended questions on gains from the experience (Table 3). Student satisfaction is an indicator of attitudes toward education. A poorly designed curriculum can be a reason for dropout. Quality of education was an important discriminator for predicting student attrition (Bee \& Beronja, 1984). Gomme and Gilbert (1984) point to research undertaken to demonstrate that the quality of education affects commitment to the institution (e.g., Bean, 1980). Tinto (1982) recognizes program quality as a key to effectiveness. Thus the university environment must meet the needs of the student. Incongruencies between individual and institutional preferences (Tinto, 1982) require attention. In this study, faculty advisors more frequently cited "personal" reasons and heavy workloads as explanations for withdrawal. These did not consistently match grounds identified by students. Stoecker et al. (1988) recommended programmatic interventions to enhance student persistence. Of course, there was also a tendency for graduates to think that their program was more difficult than others which may reflect reporter bias. However, Alexander (1980) found that discontinuers perceived their program as extremely difficult.

\section{Goal Commitment}

Uncertainty about educational goals was the second most frequently cited reason for withdrawal. Content analysis of the goals on entry revealed that persisters more frequently identified entering the profession than did dropouts. Motivation to enter for dropouts more frequently came from encouragement externally, while graduates were motivated by the desire to obtain a health professional university education. Current goals differed in that graduates wished to work as a health professional, while dropouts more frequently aimed to enter a field more suited to them (Table 3). Lindop (1987) found that unsuitability to the profession was related to student wastage. Alichnie and Bellucci's (1981) study led to a recommendation for guidance for students in defining a career goal. Stewart and Sutherland's (1988) study revealed that the most significant factor cited by $42 \%$ of freshman dropouts was uncertainty regarding future goals and objectives. Certainly clarity of educational goals has been related to persistence of adult learners (Kuh \& Cracraft, 1986). Leavers were found to have more tenuous educational plans than stayers in Gilbert and Auger's (1987) longitudinal investigation of attrition.

Stress associated with the profession was identified as the third most prevalent reason for withdrawal. Stress was of high significance in relation to student wastage in Lindop's (1987) study. Graduates may like to compare their program socially with peers and associated degree of difficulty with perceived degree of quality. In contrast, Aldrich (1987) observed that passivity, withdrawal and weak 
motivation, not anxiety, were associated with failure to complete medical school. Motivation and commitment variables were more important than social/academic integration factors in Hedl's (1987) study. Unrealistic appraisal of the profession, lack of understanding of professional role and unsuitability for the profession have been linked to attrition (Lindop, 1987; Munro, 1980). Lack or attenuation of commitment to the professional role is correlated with poor academic achievement (Ungar, 1980).

One distinctive feature of professional roles is contact with lay clientele. The fact that graduates had more direct contact with clientele may in part be accounted for by increased contact with the professions' clients in the latter part of the program. Thus, withdrawing students could be less likely to reach the stage of having direct contact with clients (only 1 withdrew in fourth year, although 8 dropped out of third year). Preparation for client contact through simulated learning experiences such as videotaping was positively associated with persistence. These results seem to indicate that experiential versus theoretical teaching strategies are successful for those students who have a large clinical/fieldwork component in their program. This seems to be a distinguishing feature for health professional schools.

\section{Dropout Decisions}

Most dropouts either planned to transfer to another university or seek employment. Hedl (1987) found that $12 \%$ of dropouts were a result of transfers to other academic programs in the university or other universities in the local area. Tinto (1982) states that a new model is needed, since most dropout results from student transfer to another institution. Hedl (1987) points out that researchers rarely consider eventual graduation. Ungar (1980) proposes that students may be dropouts from university education and continue in the future, although they may remain dropouts from a particular university.

\section{Limitations}

Limitations of this study include the small sample size of withdrawing students and the instrument design which did not include items explicitly pertaining to full-time versus part-time status. Furthermore, because this study focused on students' perceived reasons for voluntary withdrawal, grades were not identified other than as a possible reason for withdrawal (IX, Appendix A). It would have been desirable but difficult to contrast actual grades of dropouts to those of graduates in this study. Preliminary information on dropouts' GPAs for years at university solicited from student advisors/directors during the study indicated that GPAs ranged from 2.5-3.8 (none was a failing grade). Tinto's category of "grade performance" seems particularly relevant to required withdrawal.

Future research might compare students who withdraw to those in the same year who persisted, so that there is no assumption that students who withdraw are a 
homogeneous group. Length of time in university (versus predisposition) could be explored as a potential factor in the differences in academic and social integration between persisters and dropouts. Furthermore, followup of both graduates and dropouts after one year could determine if "plans for the future" were congruent with reality. The incidence of health professional student attrition might be compared to the incidence of professional attrition, which is high for many health professions. For example, goal uncertainty and professional stress may explain attrition from the workforce.

\section{SUMMARY AND IMPLICATIONS}

In summary, with reference to the initial two research questions, dropouts from the health professional schools in this Canadian university were typically younger, married, and employed; considered their program less difficult; had not participated in orientation or contacted writers' workshop, clubs, sports teams, student health, faculty advisors, or their profession's clientele. These characteristics appear to reflect facets of academic integration more than social integration. Furthermore, these attributes could be considered criteria for identifying high-risk target groups in future.

Regarding the third research question, former students cited dissatisfaction with the program/curriculum content, uncertainty about educational/occupational goals, and stress associated with the profession as the three most important reasons for voluntary withdrawal. The first two explanations are consistent with prevalent reasons cited by Pantages and Creedon (1978), specifically academic (dissatisfaction with curriculum) and motivational (uncertainty about educational and occupational goals). Thus, these top two causes mirror those identified in the general post-secondary attrition literature. The third reason, however, is perhaps unique to professional schools, specifically stress associated with that profession rather than with university education alone. Stress associated with education has been identified by other investigators (e.g., Lindop, 1987). These three grounds cited for withdrawal can be categorized as academic integration.

Several unique features of professional education may account for this unprecedented factor in student attrition - stress associated with the profession. Professional preparation programs are influenced by internal, intraorganizational and external societal forces which affect the design of educational processes leading to professional outcomes (Stark, Lowther, Hagerty \& Orczyk, 1986). Professional socialization is considered to be an interactive process whereby the professional culture and ideology is transmitted initially through an educational process, leading to the acquisition of requisite knowledge, skills, values, and roles (Jarvis, 1983). Yet, few studies of professional socialization have considered the societal structure into which professionals are socialized (Feinberg, 1983) or the social formation of professional practice and knowledge. In this context, Benner (1984) realistically discusses the conflicting socialization pressures prevailing in 
university schools for health professionals and those present in most work settings. Theory-practice dissonance exists in applied fields.

Two competencies that Stark et al. (1986) describe as outcomes of professional education could be considered particularly relevant to professional preparation for working with clientele: "contextual" competence, an understanding of the broad social, economic and cultural setting in which the profession is practised, and "adaptive" competence, the ability to adjust to new conditions in a rapidly changing society. Thus, "reflection-in-action", a term coined by Schon (1987), needs to be emphasized experientially and didactically in health professional curricula. Experiential learning opportunities can be expanded through videotapes, group experiences, and field assignments/clinical placements to diminish stress. A high quality learning environment is essential.

Measures for successful retention based on the study's results could also include preprogram professional advisement, publicized counselling and academicsupport services, explicit consultation regarding program content and expectations, interviews focusing on the applicant's knowledge of program and professional demands, comprehensive ongoing orientation programs which focus on realistic expectations of the university and the profession, career-counselling programs, maximized faculty-student interaction, learning-skills programs, effective academic-advisement programs, student followup following initial classes and personalized early counselling (see, for example, Allen et al., 1988; Beltzer, 1985; Gomme \& Gilbert, 1985; Gilbert \& Auger, 1987; Hedl, 1987; Munro, 1980; Noel, 1986; Pantages \& Creedon, 1978; Stuhr, 1987). Peer counselling and support groups can likewise diminish attrition (e.g., Brown, 1987). A variety of institutional practices have been directed at retention of adult students (Ross, 1989) as participants in support programs attain higher academic achievement and retention rates (Pinkston, 1987). The beneficial effects of support on individuals experiencing educational and occupational/professional stressors have been documented in the social-support literature. Open-ended responses to the question on services that might have helped included "student counseling with more individual attention", "more practical experience to give me a better idea of what the profession was all about", "orientation program of services and facilities open to students", "better advisers", and "student stress support group”.

\section{CONCLUSIONS}

In conclusion, academic more than social integration seemed to be a major factor in attrition of health professional students at this Canadian university. Professionalcareers counselling, academic advisement, and academic-support programs are needed to decrease stress and enhance satisfaction and goal commitment/motivation. Accordingly, the costs of health professional student attrition should be diminished by instituting pertinent measures which directly address students' perceived reasons for withdrawal and which, according to Tinto's (1975) 
framework, reduce incongruencies between individual and institutional preferences. Investigations which examine relevant variables associated with voluntary student withdrawal from Canadian health care programs could have implications for recruitment procedures, admission policies, advisor-advisee systems, and counselling programs.

\section{REFERENCES}

Aldrich, C.K. (1987). Psychiatric interviews and psychological tests as predictors of medical students' success. Journal of Medical Education, 62, 658-664.

Alexander, D.A., \& Haldane, J.D. (1980). Medical education: The discontinuer's viewpoint. Medical Education, 14, 16-22.

Alichnie, M.C., \& Bellucci, J.T. (1981). Prediction of freshmen students' success in a baccalaureate nursing program. Nursing Research, 30, 49-53.

Allen, M.E., Nunley, J.C., \& Scott-Warner, M. (1988). Recruitment and retention of black students in baccalaureate nursing programs. Journal of Nursing Education, 27, 107-116.

Anisef, P. (1989). Studying part-time in Canada's universities. A social change perspective. Canadian Journal of Higher Education, 19, 11-28.

Baird, L.L. (1985). Do grades and tests predict adult accomplishment? Research in Higher Education, 23, 3-85.

Bean, J.P. (1980). Dropouts and turnover: The synthesis and test of a causal model of student attrition. Research in Higher Education, 12, 155-187.

Bee, R.H. \& Beronja, T.A. (1984). Predicting student attrition through the utilization of discriminant analysis. College Student Journal, 314-326.

Beltzer, S. (1985). Persistence of GED and transitional students at a public community college: A test of a conceptual model. American Council on Education.

Benner, P. (1984). From novice to expert. Menlo Park, California: Addison-Wesley Publishing Co.

Billings, D.M. (1987). Factors related to progress towards completion of correspondence courses in a baccalaureate nursing programme. Journal of Advanced Nursing, 12, 743-750.

Blanc, R.A., De Buhr, L.E., \& Martin, D.C. (1984). Breaking the attrition cycle. Journal of Higher Education, 80-90.

Brown, M.L. (1987). The effects of a support group on student attrition due to academic failure. Journal of Nursing Education, 26, 324-327.

Dennison, J.D., Forrester, G.C., \& Jones, G. (1982). Degree completion at British Columbia's universities. Canadian Journal of Higher Education, 12(2), 43-57.

Devlin, L.E. (1989). Part-time students: A closer look. Canadian Journal of University Continuing Education, 15(1), 29-38.

Feinberg, W. (1983). Understanding education: Toward a reconstruction of educational inquiry. Cambridge: Cambridge University Press.

Garcia, R.D., \& Fowkes, V.K. (1987). Recruitment and retention of minority students in a physician assistant program. Journal of Medical Education, 62, 477-484.

Gilbert, S. \& Auger, M. (1987). Admission and attrition: Preliminary results of the CEASE project on university attrition. Paper presented at Canadian Society for the Study of Higher Education, Hamilton.

Gilbert, S. \& Gomme, I. (1986). Future directions in research on voluntary attrition from colleges and universities. College and University, 61, 227-238.

Gomme, I., \& Gilbert, S. (1984). Paying the cost: Some observations on the problem of post secondary student attrition. Canadian Journal of Higher Education, 14, 95-100.

Guppy, N. \& Pendakur, K. (1989). The effects of gender and parental education on participation within post-secondary education in the 1970's and 1980's. Canadian Journal of Higher Education, $19,49-62$. 
Hedl, J.J. (1987). Attrition in an undergraduate program in allied health education. Journal of Allied Health, 219-228.

Jarvis, P. (1983). Professional education. London: Croom Helm.

Kegel-Flom, P. (1986). Academic dropout or academic success: A model for prediction. American Journal of Optometry and Physiological Optics, 63, 774-780.

Knopke, H.J. (1979). Predicting student attrition in a baccalaureate curriculum. Nursing Research, $28,224-227$.

Kuh, G.D. \& Cracraft, L.W. (1984). Predicting adult learners' success in higher education.

Lindop, E. (1987). Factors associated with student and pupil nurse wastage. Journal of Advanced Nursing, 12, 751-756.

McGuire, C.H., Foley, R.P., Gorr, A., \& Richards, R.W. (1983). Handbook of health professions education: Responding to new realities in medicine, dentistry, pharmacy, nursing, allied health and public health. London: Jossey-Bass.

Munro, B.H. (1980). Dropouts from nursing education: Path analysis of a national sample. Nursing Research, 29, 371-377.

Munro, B.H. (1985). Predicting success in graduate clinical specialty programs. Nursing Research, $34,54-57$.

Nelson, R.B., Scott, T.B., \& Bryan, W.A. (1984). Pre-college characteristics and early college experiences as predictors of freshman year persistence. Journal of College Student Personnel, $25,50-54$.

Noel, L. (1986). Increasing student retention: New challenges and potential. In L. Noel (Ed.), Increasing Student Retention (pp. 1-27). San Francisco: Jossey-Bass.

Oliver, D.H. (1985). The relationship of selected admission criteria to the academic success of associate degree nursing students. Journal of Nursing Education, 24, 197-206.

Pantages, T.J., \& Creedon, C.F. (1978). Studies of college attrition 1950-1975. Review of Educational Research, 48(10), 28-34.

Parkinson, K.J. (1987). Attrition of part-time TAFE Certificate students. Payneham, Australia: TAFE National Centre for Research and Development.

Pascal, C.E. \& Kanowitch, S. (1979). Student withdrawals from Canadian universities: A study of studies. Toronto: Ontario Institute for Studies in Education.

Pascarella, E., \& Terenzini, P. (1977). Patterns of student-faculty informal interaction beyond the classroom and voluntary freshman attrition. Journal of Higher Education, 48, 540-552.

Pascarella, E.T. (1986). Long-term persistence of two-year college students. Paper presented at the Annual Meeting of the Association for the Study of Higher Education. San Antonio, Texas.

Prola, M. \& Stern, O. (1984). The effect of a freshman orientation program on student leadership and academic persistence. Journal of College Student Personnel, 9, 472-473.

Report. (1985). One in every five. A survey of adult education in Canada.

Rosenfield, P. (1988). Measuring student retention: A national analysis. Research in Nursing and Health Care, 9, 198-202.

Ross, J. (1989). Recruiting and retaining adult students in higher education. New Directions for Continuing Education, 41, 49-69.

Schon, D.A. (1987). Educating the reflective practitioner. San Francisco: Jossey-Bass.

Seither, F.F. (1980). Prediction of achievement in baccalaureate nurse education. Journal of Nursing Education, 19, 28-34.

Spady, W. (1971). Dropouts from higher education: Toward an empirical model. Interchange, 2, $38-62$.

Stark, J.S., Lowther, M.A., Hagerty, B.M., \& Orczyk, C. (1986). A conceptual framework for the study of preservice professional programs in colleges and universities. Journal of Higher Education, 57, 231-258.

Stewart, M.J., \& Sutherland, H. (1988). A needs assessment approach to planned prevention of early attrition. Journal of College Student Development, 29, 282-283.

Stoecker, J., Pascarella, E., \& Wolfe, L.M. (1988). Persistence in higher education: A 9-year test of a theoretical model. Journal of College Student Development, 29, 196-209. 
Stuhr, C. (1987). Fear and guilt in adult education: A personal account of investigations into students dropping out. Regina: A CHCC Research Service Publication.

Tinto, V. (1975). Dropouts from higher education: A theoretical synthesis of recent research. Review of Educational Research, 45, 89-145.

Tinto, V. (1982). Limits of theory and practice in student attrition. Journal of Higher Education, 6 , $687-700$.

Tinto, V. (1986). Dropping out and other forms of withdrawal from college. In L. Noel et al. (eds) Increasing Student Retention. San Francisco: Jossey-Bass.

Ungar, S. (1980). The retention problem: An analysis of enrollment attrition at a Canadian college. The Canadian Journal of Higher Education, 10, 57-74.

Welborn, R.B. (January 1986). Influences of achievement among non-traditional adult health professional students. Paper presented at Regional Conference on University Teaching, Las Cruces, New Mexico.

Appendix A

Facuity of Health Professions

Student Vithdrawal Questionnaire
a) School/college
c) Year
f) Marital Status
h) Country of origin d) Age

b) Progran

e) Sex

g) No, of Dependents

i) Language used at hone

a) Previous degree/diplona

b) Please specify

c) Hane of Institution fron which degree/oiplona was avarded

d) Enploynent wile at university: part-tine___ full-time

Plesse specify type of eaploynent

III Then you applied to enter this school/college did you:
a) complete a questionnaire
c) undergo testing of eny kind
if yes, please specify
d) participate in an orientation progran b) have an interview

Indicate which of the following university 'services' you were avare of and contacted personally while you were enrolled in this progran.

a) writer's workshop

Knew About Contacted

b) student counselling

c) Onbudsnan

d) student associations/societies

e) clubs

f) sports tean

g) student health

h) faculty adviser

i) "rap" sessions with faculty and students

j) other (please specify)

k) identify other services which night have helped you if they had been available. 
$\checkmark \quad$ Indicate nethods of instruction which you experienced wile enrolled in your program in the faculty of Health Professions which focilitate your ability to learn. Please rank in order of iaportance.
B) lectures
b) tutorials
b) seninars
d) audio/visual aids
e) individual interviews/counselling
f) other (please specify)
g) identify resources which rould have helped you to learn but were not available to you:

VI a) Have you had oirect contact (eg. given care to/coached/taught) with the clients/oatiants/students

of your particular profession?

b) Did you find this experience satisfactory?

Prior to this contact, did you prepare by:
c) role playing
d) videotaping
e) practice sessions
f) other (please specify)

VII a) Describe your najor goal when you entered this school/college:

b) Identify your prinary goal at present:

c) Describe your initial view of the profession on entry to the progran:

d) Has your view changed? If so, please describe your current thoughts about this profession.

e) What motivated you to enter this school/college?

VIII Did you hrve close friend(s) in the:
a) School/college
o) University
c) City

d) Is your progran aore or less difficult than the progran of friends or acquaintances in other schools/departnents/faculties? Explain.

e) How of ten did you ususlly comsunicate with (eg. individual neetings, face-face contact) faculty nenbers teaching your courses?

Never Seldom Sonetines Frequently

IX Please rank order the three most important reasons that you are withdrawing fron this school/college:

a) dissatisfaction with canpus social life

b) financial difficulty

c) moving to another province/country

d) acadenic failure/ooor grades

e) dissatisfaction with the progran/curriculun content

f) difficulty sojusting to the University

g) personal illness or injury

h) fanily illness or injury

i) marriage

j) dissatisfaction with ability/knowledge of professors

k) lack of support/assistance at university

l) inadequate stuóy habits/rork skills

w) uncertainty about educational/occupational gos ls

n) stress associated with university education

o) stress associated with profession

p) other (please specify)

$x \quad$ a) Do you consider your withdrawal: tomporary permanent

b) Do you plan to: transfer to another school in this profession ___; transfer to another health related school _ i transfer to another faculty ___; seek enploynent___; other (please specifyl

c) Do you believe that you have gained anything fron your experience at this School/college? Please convent. 